\title{
VALIDITAS KONSTRUK ALAT UKUR KESALEHAN SOSIAL
}

\author{
Istiqomah \\ Fakultas Psikologi Universitas Muhammadiyah Malang \\ istiqomah@umm.ac.id
}

\begin{abstract}
Abstrak. Alat ukur kesalehan sosial adalah alat ukur yang terdiri dari 41 item dengan tujuh dimensi yang diukur yaitu (a) solidaritas sosial (al-takaful al-ijtima'i), (b) toleransi (al-tasamuh), (c) mutualitas/kerjasama (al-ta'awun), (d) tengah-tengah (al-I'tidal), dan (e) stabilitas (al-tsabat) (f) menolong dan (g) kejujuran. Tujuan dari pengembangan alat ukur ini adalah untuk mengembangkan alat ukur kesalehan sosial, menguji validitas dan reliabilitas alat ukur kesalehan sosial dan mendeskripsikan tingkat kesalehan sosial karyawan. Subjek penelitian adalah karyawan pada beberapa perusahaan dan karyawan pada instansi pemerintah. Hasil analisis data menunjukkan dari 41 item yang dikembangkan terdapat 14 item yang gugur dan 27 item yang valid dengan reliabilitas sebesar 0,797 .
\end{abstract}

Kata Kunci: Validitas Konstruk, Alat Ukur Kesalehan Sosial

\begin{abstract}
The measure of social piety is a instrument consisting of 41 items with seven dimensions measured there are (a) social solidarity (al-takaful al-ijtima'i), $(b)$ tolerance (al-tasamuh), (c) mutuality / cooperation (al-ta'awun), (d) midst (al-I'tidal), and (e) stability (al-tsabat) $(f)$ help and $(g)$ honesty. The purpose of the development of this measuring instrument is to develop a instrumen of social piety, test the validity and reliability of measuring instruments of social piety and describe the level of employee social piety. The research subjects were employees of several companies and employees of government agencies. The results of data analysis showed that from 41 items developed there were 14 items that were dropped and 27 items were valid with reliability of 0.797 .
\end{abstract}

Keywords: Construction Validity, Social Piety Measurement Tool 
Kesalehan merupakan penghayatan dan pengamalan ajaran agama secara sempurna. Seorang muslim mengamalkan ajaran islam berarti mengamalkan ajaran islam dan berada pada proses pencapaian kesalehan. Pengamalan yang terus menerus terhadap ajaran islam menjadi awal tertanamnya kesalehan dalam jiwa setiap muslim. Perintah menjalankan agama tujuan utamanya adalah mencetak hamba Allah yang sholeh yang tidak hanya berakibat positif pada dirinya tetapi juga pada lingkungannya.

Islam memiliki nilai yang secara universal mengajarkan umatnya untuk senantiasa berubah dari kejelekan menuju kebaikan (transformatif) yakni Allah tidak merubah keadaan suatu kaum sehingga mereka merubah keadaan yang ada pada diri mereka sendiri. Ajaran Islam inilah hadir untuk selalu mengentas manusia dari berperadaban rendah menuju manusia yang berperadaban tinggi. Ajaran Islam inilah yang juga menjadi kekuatan pendidikan Islam untuk selaras dengan misi utama Nabi yang diutus oleh Allah untuk memperbaiki karakter dan perilaku ummat. Perbaikan karakter dan perilaku merupakan bagian sangat penting untuk membangun kualitas hidup dan peradaban manusia, dengan transformasi kesalehan individu menuju kesalehan sosial diharapkan individu mampu menghadapi gencarnya arus globalisasi.

Kesalehan sosial adalah sebagai kesalehan yang menunjukkan pada prilaku orang yang peduli dengan dengan nilai-nilai Islami, yang bersifat sosial. Proses terbentuknya kesalehan sosial dapat di-lacak dari interseksi antara aspek material dan aspek spiritual dalam beribadah. Spiritual dipahami sebagai usaha untuk mendekatkan diri kepada Sang Khalik, sementara material dapat dipandang sebagai alat penujang spiritual tersebut. Menjadi orang saleh memang menjadi tujuan utama kesalehan sosial ini, namun yang lebih penting lagi adalah pengakuan dan afirmasi dari masyarakat terhadap kesalehan sosial yang dkonstruksikan tersebut.

Kesalehan menjadi motivator pembentukan sifat terpuji dalam kehidupan nyata. Hal ini dikarenakan kesalehan menumbuhkan kesadaran dan keyakinan bahwa ajaran islam hanya mengajarkan sesuatu yang baik dan terpuji. Kesadaran ini pada gilirannya mendorong pemiliknya untuk mengajak orang lain menjadi saleh. Dengan demikian orang yang saleh memiliki kepekaan yang tinggi terhadap lingkungan sekitarnya (Helmi, 2014).

Dalam Al Qur an Allah menjelaskan dua kategori indikator kesalehan manusia yaitu kesalehan individual dan kesalehan sosial. Kesalehan individual adalah kemampuan bersyukur kepada Allah atas nikmat yang diberikan kepadanya atau orang-orang yang dicintainya dan keteguhannya dalam berbuat amal sholeh (Habblum minnallah). Kedua adalah kesalehan sosial, indikatornya adalah mempunyai kepekaan sosial yang tinggi yang berawal dari keinginannya untuk memberdayakan orang orang disekelilingnya (hablum-minnas).

Sebagai perilaku keagamaan, konsepsi Islam tersebut lebih dapat menjelaskan tentang kesalihan sosial sebagai bagian dari perbuatan manusia. Hal ini didasari beberapa pemikiran yaitu, pertama, perbuatan manusia banyak didasari atas kehendak dirinya dan tidak bisa semata-mata didasari atas determinan sebagaimana dalam psikoanalisa, atau sebagai diri. yang tidak memiliki kesadaran laksana kapas yang diterbangkan angin seperti dalam behaviorisme, atau peniruan sebagaimana dikenal dalam teori modelling. Kedua, salah satu karakteristik manusia adalah adanya kesadaran untuk selalu introspeksi, berdialog dengan dirinya sendiri, dan selalu berhubungan dengan lingkungan 
alam fisik. Manusia selalu berinteraksi dengan diri sendiri, lingkungan sekitar, dan alam keruhanian. Semenjak awal telah menjelaskan bahwa manusia adalah satu-satunya makhluk yang dalam unsur penciptaannya terdapat ruh Ilahi. Kesalihan sosial adalah bagian dari interaksi seseorang dengan pengalaman keruhaniannya. Ketiga, sebagai makhluk berkesadaran, perilaku manusia didasari atas pilihan dan putusan rasional. Maka perilaku manusia seharusnya bisa terlepas dari pengaruh lingkungan sekitarnya. Seorang yang salih akan tetap salih meski lingkungan sekitarnya banyak kriminalitas, korupsi, dan kejahatan lainnya.

Kesalehan sosial merupakan orientasi religious individu dimana tidak hanya berhubungan dengan Allah tetapi juga merupakan orientasi religious individu dalam berinteraksi dengan sesama. Moltafet, Mazidi, \& Sadati, (2010) dalam penelitiannya menyatakan bahwa terdapat hubungan yang signifikan antara orientasi religious dengan dengan dimensi kepribadian.

Teori dalam psikologi yang bisa dekat dengan konsep kesalehan sosial adalah konsep hasrat untuk hidup bermakna (the will to meaning) yang dikemukakan Viktor Frankl. Konsep "hidup bermakna" adalah motivasi utama setiap manusia, konsep ini deperkuat dengan konsep "hati nurani" Frankl, Menurut Frankl hati nurani adalah semacam spiritualitas alam bawah sadar, yang sangat berbeda dengan insting-insting alam bawah sadar seperti yang dikemukakan Frued. Teori lain yang memiliki aspek-aspek yang memiliki kesamaan dengan kesalehan sosial adalah prososial. Prososial adalah peaku yang memiliki konsekuensi positif terhadap orang lain (Baron R.A.\& Byrne, 2004). Perilaku prososial meliputi menolong, berbagi rasa, kerja sama menyumbang dan memperhatikan kesejahteraan orang lain.

Kesalihan sosial adalah bentuk perilaku keagamaan seseorang yang lahir dari sikap keagamaan, sementara sikap keagamaan lahir dari pemahaman seseorang atas nilai-nilai yang difahami (kognitif), dirasakan (afektif), dan dilakukan (konatif). Penelitian yang dilakukan oleh (Aghababaei, 2014) yang meneliti tentang korelasi antara religiusitas, well being dan personality menunjukkan bahwa religiusitas berkorelasi positif dengan keadilan. Sedangkan salah satu aspek dalam kesalehan sosial dan prososial adalah keadilan.

Penelitian yang dilakukan oleh (Miyatake \& Higuchi, 2017) menunjukkan bahwa orientasi keagamaan dapat meningkatkan perilaku prososial individu dimana perilaku tersebut merupakan dasar dalam menumbuhkan perilaku membantu, berbagi antar sesama. Konsep yang ditanamkan adalah bahwa dalam kegiatan mereka sehari hari selalu diawasi oleh tuhan.

Berdasarkan pemaparan diatas maka dibutuhkan alat ukur yang dapat mengungkap tentang Kesalehan Sosial. Alasan utamanya adalah belum ada alat ukur yang mengungkap tentang kesalehan sosial. Studi ini merupakan studi awal dalam pengembangan alat ukur dan pengujian validitas konstruk alat ukur kesalehan sosial.

Tujuan Penelitian dari penelitian ini adalah:

1. Mengembangkan alat ukur kesalehan sosial

2. Menguji validitas dan reliabilitas alat ukur kesalehan sosial

3. Mendeskripsikan tingkat kesalehan sosial pada masyarakat beragama di Indonesia 


\section{Manfaat Penelitian:}

1. Memberikan khasanah baru dalam bidang psikologi Agama tentang pengembangan alat ukur kesalehan sosial.

2. Dari pengembangan dan pengujian validitas dan reliabilitas alat ukur kesalehan sosial akan diperoleh alat ukur psikologi yang memenuhi prinsip-prinsip pengukuran (psikometri).

Kesalehan sosial dipahami sebagai kesalehan yang menunjukkan pada prilaku orang yang peduli dengan dengan nilai-nilai Islami, yang bersifat sosial. Maka yang terpenting sekarang adalah menjadikan satu ibadah tidak hanya bernilai kesalehan individu tapi sekaligus bernilai kesalehan sosial. Sehingga ibadah itu tidak terdikhotami antara individu dan social (Riadi H, 2014).

Kesalehan Sosial menunjuk pada perilaku orang-orang yang sangat peduli dengan nilainilai islami, yang bersifat sosial. Bersikap santun pada orang lain, suka menolong, sangat concern terhadap masalah-masalah ummat, memperhatikan dan menghargai hak sesama; mampu berpikir berdasarkan perspektif orang lain, mampu berempati, artinya mampu merasakan apa yang dirasakan orang lain, dan seterusnya. Kesalehan sosial dengan demikian adalah suatu bentuk kesalehan yang tak cuma ditandai oleh rukuk dan sujud, puasa, haji melainkan juga ditandai oleh seberapa besar seseorang memiliki kepekaan sosial dan berbuat kebaikan untuk orang-orang di sekitarnya. Sehingga orang merasa nyaman, damai, dan tentram berinteraksi dan bekerjasama dan bergaul dengannya.

Kesalehan sosial adalah perilaku orang-orang yang sangat peduli dengan nilai-nilai Islami, yang bersifat sosial. Suka memikirkan dan santun kepada orang lain, suka menolong, meskipun orang-orang ini tidak setekun kelompok yang sangat taat dalam melakukan ibadah seperti sembayang dan sebagainya tetapi lebih mementingkan hablun minan naas (Bisri H, 2018). Boleh jadi hal itu memang bermula dari fenomena kehidupan beragama kaum Muslim itu sendiri, dimana memang sering kita jumpai sekelompok orang yang tekun beribadat, bahkan berkali-kali haji misalnya, namun kelihatan sangat bebal terhadap kepentingan masyarakat umum, tak tergerak melihat saudara-saudaranya yang lemah tertindas, misalnya. Seolah-olah Islam hanya mengajarkan orang untuk melakukan hal-hal yang dianggapnya menjadi hak Allah belaka. Sebaliknya juga, sering dijumpai orang-orang Islam yang sangat concern terhadap masalah-masalah ummat, sangat memperhatikan hak sesamanya, kelihatan begitu mengabaikan ibadat pribadinya.

Definisi Konseptual, kesalehan sosial adalah sikap seseorang yang memiliki unsur kebaikan (salih) atau manfaat dalam kerangka hidup bermasyarakat. Sikap kesalehan sosial tersebut meliputi: (a) solidaritas sosial (al-takaful al-ijtima'i), (b) toleransi (altasamuh), (c) mutualitas/kerjasama (al-ta'awun), (d) tengah-tengah (al-I'tidal), dan (e) stabilitas (al-tsabat).

Kesalihan sosial adalah bentuk perilaku keagamaan seseorang yang lahir dari sikap keagamaan, sementara sikap keagamaan lahir dari pemahaman seseorang atas nilai-nilai yang difahami (kognitif), dirasakan (afektif), dan dilakukan (konatif). Salah satu teori yang mungkin bisa menggambarkan tentang kesalehan sosial adalah adanya teori tentang prososial yaitu perilaku prososial merupakan tindakan altruisme yang tidak mementingkan diri sendiri atau tanpa pamrih sampai tundakan menolong yang 
sepenuhnya dimotivasi oleh diri sendiri Rushton ( dalam Sears, dkk. 2005). Perilaku prososial didefinisikan sebagai sebagai perilaku yang memiliki konsekuensi positif pada orang lain. Bentuk yang paling jelas dari prososial adalah perilaku menolong. Lebih spesifik lagi, Eisenberg dan Mussen (dalam Dayakisni,2009) memberi pengertian perilaku prososial mencakup pada tindakan-tindakan: sharing (membagi), cooperative (kerjasama), donating menyumbang, helping (menolong), honesty (kejujuran) generosity (kedermawanan) serta mempertimbangkan hak dan kesejahteraan orang lain.

Kajian ini menggunakan teori sebagaimana dalam teori prososial karena adanya kesesuaian dengan pandangan para pemikir Islam bahwa manusia adalah makhluk yang memiliki kesadaran sebagai 'khalifah' Tuhan. Sehingga kesadaran inilah yang dianggap menentukan perbuatan seseorang yang berulang-ulang terhadap objek social bukan karena adanya pengaruh sosial Pertama, kesalehan sosial adalah sikap seseorang yang memiliki unsur kebaikan (salih) atau manfaat dalam kerangka hidup bermasyarakat. Sikap kesalehan sosial bisa meliputi: (a) solidaritas sosial (al-takaful al-ijtima'i), (b) toleransi (al-tasamuh), (c) mutualitas/kerjasama (al-ta'awun), (d) tengah-tengah (alI'tidal), dan (e) stabilitas (al-tsabat). Kedua, kesalehan sosial dalam perspektif tokohtokoh muslim adalah berangkat dari kesadaran manusia sebagai makhluk Tuhan yang bertanggung jawab atas kehidupan di bumi dan sekaligus menjalankan tugas sebagai 'wakil Tuhan' (khalifah) di bumi, Ketiga, dalam psikologi kognitif dikenal adanya bentuk kesadaran dalam diri individu yaitu teori tentang konsep diri yang berasal dari dimensi pengetahuan, dimensi pengharapan, dan dimensi penilaian. Konsep diri inilah yang menentukan perbuatan seseorang, yang berulang-ulang terhadap objek sosial. Keempat, kesalehan sosial sebagai attitude atau sikap mempunyai tiga aspek yaitu kognitif, afektif, dan konatif. Sikap bisa berubah dalam hal intensitasnya, namun biasanya konsisten sepanjang waktu dalam situasi yang sama, dan komposisinya hampir selalu kompleks. Kelima, kesalehan sosial merupakan salah satu bagian dari capaian seseorang dalam memberikan "pemaknaan" terhadap hidupnya di bumi (will to meaning).

Penelitian Kesalehan sosial secara khusus juga pernah dilakukan oleh Mohammad Sobary dengan judul Kesalehan Sosial (Influence of Islamic piety on the rural economic behavior in Suralaya, Jawa Barat Province. 2007, Yogyakarta: LKiS) Penelitian ini merupakan tesis Sobary di Universitas Monash, Australia. Sobary dalam tesisnya ini, mengungkap peranan Agama dalam mewujudkan hubungan yang positif antara "Kesalehan" dan "Tingkah Laku Ekonomi" di Desa Suralaya. Oleh karena itu, penelitian etnografis yang dilakukannya berupaya untuk menemukan beberapa konsep kunci yang sangat penting dalam menemukan peranan agama dalam masyarakat Suralaya.

Kesalehan sosial telah diteliti sebelumnya oleh (Zuhri, 2014) mengenai Pendidikan Transformasi Kesalehan Individu Menuju Kesalehan Sosial Hasil penelitiannya adalah pertama; transformasi kesalehan individu menuju kesalehan sosial dapat tercapai dengan tiga proses yakni individu memahami fungsi agama Islam secara transformatif, individu memahami peran agama Islam secara transformatif dan individu mampu mentransformasikan Islam. Kedua; dampak globalisasi terhadap perkembangan pendidikan Islam yakni globalisasi sangat mempengaruhi masyarakat, dimana sebarannya sangat luas dari orang dewasa sampai anak-anak. Akibatnya paedagogi pesrta didik tidak 
luput dari arusnya sehingga karakter, potensi dan akhlak (tingkahlaku) ikut terpengaruh dengan tren globalisasi. Ketiga, cara pendidikan Islam mentransformasikan kesalehan individu menuju kesalehan sosial di era global adalah pentransformasian dilakuakan secara teoritis dan praktis.

Penelitian lain dilakukan oleh Greedy M. A (2003) meneliti tentang kesalehan sosial dan pragmatisme yang merupakan trens politik islam di Indonesia. Ada kecenderungan politik Islam di Indonesia dilakukan oleh pemerintah dan mereka kurang menerapkan nilai kesalehan sosial.

Penelitian yang dilakukan oleh Riadi H (2014) mengenai kesalehan sosial sebagai parameter kesalehan keberislaman menyimpulkan bahwa Islam mengutamakan kehidupan sosial, maka kesalehan sosial sebagai parameter kesalehan keberagamaan perlu dibangun. Pada sisi lain, konsep tauhid serta ibadah tidak akan bermakna bila tidak dipahami dalam perspektif sosial. Karenanya merupakan suatu keniscayaan mengukur kesalehan seseorang dalam perspektif sosial. Maka upaya yang dilakukan adalah mengembalikan semua bentuk ajaran kedalam praktek yang bernilai sosial dan merupakan kesadaran kesalehan sosial.

Aspek alat ukur Kesalehan Sosial antara lain (Mahfud S, 1994) :

a) Solidaritas sosial adalah kesediaan untuk memberi dan peduli kepada orang lain tanpa mengharapkan imbalan.

b) Kerja sama atau mutualitas adalah melakukan pekerjaan atau aktivitas secara bersama sama berdasarkan kesepakatan untuk mencapai tujuan bersama pula.

c) Toleransi ialah mampu menghargai perbedaan nilai-nilai kehidupan, tidak memaksakan nilai pada orang lain serta tidak menghina atau merusak nilai yang berbeda.

d) Adil dan seimbang merupakan perilaku yang mampu bertindak sesuai dengan proporsi, tersedianya kesempatan yang sama dalam bekerja dan beraktualisasi.

e) Menjaga ketertiban umum yaitu suatu tindakan yang berhubungan dengan orang lain tanpa mengganggu, merugikan dan melanggar kesejahteraan orang lain.

Eisenberg dan Mussen (dalam Dayakisni, 2009) memberi pengertian prososial sebagai tindakan yang mencakup:

a. Sharing (membagi) yaitu memberikan kesempatan kepada orang lain untuk dapat merasakan sesuatu yang dimilikinya termasuk keahlian dan pengetahuan

b. Cooperative (kerjasama) yaitu melakukan kegiatan bersama dengan orang lain untuk mencapai tujuan bersama termasuk mempertimbangkan dan menghargai pendapat orang lain dalam berdiskusi

c. Donating (menyumbang) adalah perbuatan yang memberikan secara materiil kepada seseorang atau kelompok untuk kepentingan umum yang berdasarkan pada permintaan, kejadian dan kegiatan.

d. Helping (menolong) adalah membantu orang lain secara fisik untuk mengurangi beban yang sedang dilakukan

e. Honesty (kejujuran) adalah tindakan dan ucapan yang sesuai dengan keadaan yang sebenarnya

f. Generosity (kedermawanan) ialah memberikan sesuatu kepada orang laian atas dasar kesadaran diri 
g. Mempertimbangkan hak dan kesejahteraan orang lain ialah suatu tindakan untuk melakukan suatu hal untuk kepentingan pribadi yang berhubungan dengan orang lain tanpa mengganggu dan melanggar kesejahteraan orang lain.

Aspek aspek kesalehan sosial yang sama dengan aspek teori psikologi prososial adalah solidaritas dengan donating, helping dan kooperatif, sharing dengan adil, dalam kedua konstruk tersebut memiliki aspek sama yaitu kerja sama, serta menjaga ketertipan umum dengan mempertimbangkan hak dan kesejahteraan orang lain.

Validitas adalah ketepatan tes dalam mengukur sesuatu yang harus diukur. Gronlund (1982) secara umum mengartikan validitas sebagai sejauh mana hasil tes dapat dipakai untuk tujuan yang dimaksudkan. Dengan perkataan lain validitas adalah kesesuaian tafsiran mengenai hasil tes.

Azwar (2013) mengemukakan suatu alat ukur dikatakan mempunyai validitas yang tinggi apabila tes tesebut menjalankan fungsi ukurnya atau memberikan hasil ukur yang tepat dan akurat sesuai dengan maksud dikenakannya tes tersebut. Suatu alat ukur yang tinggi validitasnya akan memili error pengukuran yang kecil, artinya skor setiap subjek yang diperoleh alat ukur tersebut tidak jauh berbeda dari skor yang sesungguhnya. Suatu tes dikatakan valid jika tes tersebut mengukur apa yang hendak diukur (Allen dan Yen, 1979).

Validitas tes terdiri dari validitas isi, validitas konstruk, dan validitas berdasarkan kriteria (validitas berdasarkan kriteria terdiri atas validitas prediktif dan validitas konkuren).Validitas isi tes menunjuk sejauh mana seperangkat soal-soal dilihat dari isinya memang mengukur apa yang dimaksudkan untuk diukur. Validitas konstruk mempersoalkan skor-skor hasil pengukuran dengan instrumen itu merefleksikan konstruksi teori tes yang mendasari penyusunan alat ukur tersebut. Validitas kriteria dlihat dari sejauh mana hasil pengukuran dengan alat ukur yang dipersoalkan itu sama atau mirip dengan hasil pengukuran lain yang dijadikan ukuran, dimana kriteria itu dapat dalam waktu sekarang atau waktu yang sesaat dan kriteria diwaktu yang akan datang. Jika kriteria itu sekarang atau dalam waktu dekat dapat dimanfaatkan disebut validitas konkuren, dan jika kriteria itu baru beberapa waktu kemudian dapat dimanfaatkan disebut validitas prediktif.

Analisis factor adalah prosedur untuk mengidentifikasi item atau variable berdasarkan kemiripannya.Kemiripan tersebut ditunjukkan dengan korelasi yang tinggi. Item-item yang memiliki korelasi yang tinggi akan membentuk satu kerumunan factor (Widiarso, 2009).

Pada analisis factor memungkinkan peneliti untuk 1) menguji ketepatan model (goodness of fit tes) factor yang terbentuk dari item-item alat ukur 2) menguji kesetaraan unit pengukuran antar aitem, 3) menguji reliabilitas item-item pada tiap factor yang diukur, 4) menguji adanya invariant item pada populasi. Jenis Analisis factor (1) Analisis factor eksploratori (exploratory Factor Analisi) Suatu analisis yang digunakan untuk mengetahui atau mengidentifikasi factor yang ada di dalam seperangkat item tersebut. (2) Analisis factor Konfirmatory (confirmatory Factor Analisis.)Analisis factor yang digunakan untuk menguji suatu alat ukur yang telah diketahui dimensinya. Jadi untuk membuktikan bahwa alat ukur tersebut memang terbukti terdiri dari beberapa factor. 


\section{METODE}

Definisi operasional kesalehan sosial adalah kesalehan sosial yang menunjukkan pada prilaku individu yang peduli dengan dengan nilai-nilai Islami yang bersifat sosial. Bersikap santun pada orang lain, suka menolong, sangat concern terhadap masalahmasalah ummat, memperhatikan dan menghargai hak sesama; mampu berpikir berdasarkan perspektif orang lain, mampu berempati, artinya mampu merasakan apa yang dirasakan orang lain, dan seterusnya.

Subjek penelitian adalah sumber utama data penelitian, yaitu yang memiliki data mengenai yang diteliti Subjek penelitian yang akan digunakan adalah karyawan perusahaan.Pada penelitian ini patokan jumlah subjek yang digunakan adalah menurut Gable yaitu enam sampai sepuluh kali lipat banyaknya item. Jumlah item skala ini adalah 41 item, jadi subjek penelitian ini adalah antara 240-400 karyawan lebih tepatnya adalah 343 subjek. Penelitian ini dilaksanakan pada perusahaan atau instansi pemerintah yang ada di kota.

Prosedur pelaksanaan penelitian ini melalui tiga tahapan yaitu:

Proses penyusunan skala Kesalehan Sosial

a. Identifikasi tujuan ukur/penetapan konstruk psikologi

Salah satu cara untuk memudahkan identifikasi tujuan ukur adalah dengan menguraikan komponen-komponen atau faktor faktor yang ada dalam konsep teoritik mengenai atribut yang hendak diukur.

b. Operasionalisasi konsep, indikator perilaku (disajikan dalam bentuk blue print), yaitu: (1) dimensi menjelaskan adanya aspek ukur unik yang memiliki domain yang berbeda dengan aspek lainnya. Untuk mengetahui bahwa aspek tersebut merupakan dimensi yang berbeda biasanya dilakukan analisis faktor. Analisis faktor akan menghasilkan faktor-faktor (kadang dinamakan dimensi); (2) aspek adalah penjabaran konstrak ukur yang lebih operasinal sebelum dijabarkan lagi menjadi indikator indikator perilaku yang lebih operasional. Aspek-aspek inilah yang pada akhirnya djabarkan menjadi indikator dan item dalam skala; (3) aspek merupakan domain-domain ukur teoritik yang belum diuji apakah masing-masing memiliki independensi ataukah tidak. Jika masing-masing domain teoritik tersebut memiliki independensi yang dibuktikan dengan analisis faktor maka dinamakan dengan dimensi atau faktor. (4) Indikator perilaku adalah bentuk-bentuk perilaku yang mengindikasikan ada tidaknya suatu atribut psikologis. (5) Blue Print skala psikologi disajikan dalam bentuk tabel, yang memuat uraian komponen-komponen atribut yang harus dibuat itemnya, proposi item dalam masing masing komponen, serta indikator perilaku dalam setiap komponen. Blue print akan memberikan gambaran mengenai isi skala dan menjadi pedoman bagi penulis untuk tetap berada dalam lingkup pengukuran yang benar.

c. Penskalaan dan pemilihan format stimulus

Penskalaan digunakan untuk menentukan skor pada masing-masing item setelah diuji cobakan. Model penskalaan ini yang digunakan dalam penyusunan skala perkembangan moral ini adalah pendekatan respon (skala likert).

d. Penulisan Item (review item) 
e. Analisis Item

Analisis item dalam skala psikologi meliputi seleksi item (korelasi item-total) menggunakan formula koefisien korelasi product moment, dan dilanutkan dengan melakukan koreksi terhadap efek suporious overlap.

f. Kompilasi I (seleksi item)

Item yang dinyatakan valid adalah apabila korelasi antara item-total > dari 0,30. Validitas item juga dapat ditentukan berdasarkan $r$ tabel.

d. Pengujian Reliabilitas

Pengujian reliabilitas dilakukan pada sejumlah item yang telah dinyakan valid.

e. Validasi

Validasi dilakukan dengan menyusun ulang nomer item jadi sesuai dengan blue print serta banyakya item pada masing-masing aspek yang diukur.

f. Kompilasi II (format final)

Skala siap untuk di gunakan.

Tahap Pelaksanaan Penelitian

Uji coba tes dilaksanakan mungkin cukup sekali atau lebih sampai mendapatkan butir soal yang memenuhi kriteria. Suryabrata (2000) menyatakan jika satu kali uji coba sudah mendapatkan tes yang memadai maka uji coba cukup dilakukan satu kali. Penelitian dilakukan dengan memberikan alat ukur kepada subjek penelitian untuk diisi secara lengkap.

\section{HASIL}

Berdasarkan hasil analisis data pada alat ukur kesalehan sosial dengan menggunakan korelasi item - total dengan Product Moment terdapat 27 item yang diterima dan 14 item yang tidak diterima.

\section{Tabel 1. Item Yang Valid}

\begin{tabular}{|c|c|c|}
\hline No & Aspek & Item \\
\hline 1 & Solidaritas & $2,6,32,12$ \\
\hline 2 & Kerja Sama & $1,13,22,20,27$ \\
\hline 3 & Toleransi & $3,40,18$ \\
\hline 4 & Adil dan seimbang & $5,15,24,8,17$ \\
\hline 5 & Mempertimbangkan kesejahteraan umum & $9,16,36$ \\
\hline 6 & Menolong & $33,4,39,35$ \\
\hline 7 & Kejujuran & $34,23,31$ \\
\hline
\end{tabular}

Seleksi item ditentukan dengan menggunakan $r$ tabel sebesar 0,09 dengan df 342. Alasan menggunakan $\mathrm{r}$ tabel adalah banyak terdapat item yang korelasi item dengan totalnya kurang dari 0,30 sehingga tidak menggunakan patokan korelasi item - total > 0,30. Dari patokan $\mathrm{r}$ tabel mengakibatkan reliabilitasnya rendah sehingga peneliti 
memutuskan dengan menggunakan $r=0,150$ dimana dengan patokan ini dapat mengukur seluruh kawasan domain ukur dan reliabilitasnya terpenuhi. Reliabilitas alat ukur sebesar 0, 797. Dari tujuh aspek semua itemnya terwakili sehingga alat ukur ini bisa digunakan dan telah memenuhi seluruh kawasan domain ukur.

\section{Tabel 2: Item Alat Ukur Kesalehan Sosial}

\begin{tabular}{|c|c|}
\hline No & Solidaritas Sosial \\
\hline 2 & Berpartisipasi dalam kegiatan sosial dilingkungan kerja \\
\hline 6 & Peduli dengan rekan kerja yang sakit atau kesusahan \\
\hline 32 & Menyisihkan sebagian gaji untuk orang-orang yang kurang mampu \\
\hline 12 & Menghindari kegiatan sosial yang melibatkan seluruh karyawan \\
\hline No & Kerja Sama \\
\hline 1 & Saya akan bekerja sama dengan divisi lain untuk meningkatkan kinerja \\
\hline 13 & Menyelesaikan tugas sesuai dengan prosedure \\
\hline 22 & Menyelesaikan tugas sesuai dengan batas waktu yang telah ditentukan \\
\hline 20 & Saya kurang memperhatikan benar atau salah dari tugas yang sudah terselesaikan \\
\hline 27 & Saya hanya diam dan mendengarkan saja ketika rapat sedang berlangsung \\
\hline No & Toleransi \\
\hline 3 & Menghargai rekan kerja yang berbeda keyakinan \\
\hline 40 & $\begin{array}{l}\text { Menghargai rekan kerja yang mengambil cuti untuk kegiatan yang berbeda } \\
\text { dengan saya }\end{array}$ \\
\hline 38 & $\begin{array}{l}\text { Menarik diri ketika melihat adanya perbedaan agama dan budaya dengan rekan } \\
\text { kerja }\end{array}$ \\
\hline No & Adil dan seimbang \\
\hline 5 & Memilih menjadi penengah jika ada perselisihan di tempat kerja \\
\hline 15 & Memberikan kesempatan kepada orang lain untuk menyampaikan pendapatnya \\
\hline 24 & Menerima rekan kerja dengan kemampuan yang berbeda -beda \\
\hline 8 & Saya bekerja dengan memprioritaskan kenaikan pangkat bagi yang satu visi \\
\hline 17 & Saya bahagia ketika mendapatkan gaji yang lebih tinggi dari rekan kerja \\
\hline No & Mempertimbangkan kesejahteraan umum \\
\hline 9 & Terlibat dalam upaya perbaikan kinerja \\
\hline 16 & Memilih diam jika ada yang menyalahi aturan dalam bekerja \\
\hline 36 & Menjaga ketertiban dan kebersihan di lingkungan kerja \\
\hline No & Menolong \\
\hline 33 & Saya akan membantu tugas rekan kerja ketika sudah menyelesaikan tugas pribadi \\
\hline 4 & $\begin{array}{l}\text { Meskipun berilmu, berhata serta memiliki kedudukan yang tinggi, Saya akan } \\
\text { menolong siapapun }\end{array}$ \\
\hline 39 & Saya bersedia menggantikan tugas rekan kerja yang mengalami musibah \\
\hline 35 & Membantu rekan kerja yang mengalami kesulitan \\
\hline No & Kejujuran \\
\hline 34 & $\begin{array}{l}\text { Saya menghindari untuk memanfaatkan fasilitas di tempat kerja untuk } \\
\text { kepentingan pribadi }\end{array}$ \\
\hline 23 & Menjaga amanah yang dipercayakan kepada saya dengan sebaik baiknya \\
\hline 31 & Saya selalu memanipulasi hasil kerja \\
\hline
\end{tabular}


Kesalehan sosial pada karyawan bisa dikategorikan melalui skor $\mathrm{T}$, hasil selengkapnya dapat dilihat pada tabel berikut:

Tabel 3: $\mathbf{T}$ score

\begin{tabular}{|c|c|c|c|c|}
\hline No & Kategori & Skor T & Jumlah & prosentase \\
\hline 1 & Tinggi & $>50$ & 174 karyawan & $49,28 \%$ \\
\hline 2 & Rendah & $\leq 50$ & 169 Karyawan & $50,72 \%$ \\
\hline
\end{tabular}

\section{DISKUSI}

Analisis data penelitian ini menggunakan korelasi item dengan total dan terdapat 27 item yang valid. Analisis selanjutnya adalah analisis faktor yaitu confirmatory faktor analisis. Confirmatory faktor analisis ini untuk menguji apakah item item tersebut sudah sesuai dengan faktornya atau tumpang tindih dengan aspek aspek yang lainnya. Dalam confirmatory faktor analisis terdapat asumsi asumsi yang harus dipenuhi yaitu goodness of Fit. Ada tiga formula untuk menentukan goodnes of fit dan tergantung peneliti menggunakan model yang dipilih. Dalam penelitian ini peneliti menggunakan RMSEA, CFI dan GFI. RMSEA < 0,8 CFI dan GFI > 0,90. Uji goodnes of fit tidak memenuhi GFI CFI dan RMSEA tidak memenuhi sehingga item yang memiliki faktor loading < dari 0,50 dihapus $(3,5,16,17,21,27,30,34,38)$. Hasil goodness of fit tetap belum memenuhi sehingga mengkovariankan Langkah selanjutnya adalah mengkovariankan antar error sesuai dengan saran modifikasi index karena masih belum fit maka dilakukan pengurangan pada item yang masih memiliki faktor loadimg, dari 0,50 yaitu (item 20 dan 21) serta konstain 1 pada masing masing faktor. Tetapi blm memenuhi goones of fit bahkan hasilnya error karena dalam satu faktor hanya ada satu item yang faktor loadingnya diatas 0,50 sehingga alat ukur ini tidak dapat dianalisis menggunakan confirmatory factor analisis. Sejalan dengan penelitian yang dilakukan oleh (Bufford et al., 2015) yang meneliti tentang Dimensi Rahmad yang mengulas tentang analisis faktor dimensi Rahmad yang terdiri dari tiga faktor. Dalam analisis tersebut tidak dapat dilakukan confirmatory factor analisis karena dimensi Rahmat merupakan dimensi religiusitas yang di gabung dengan Konstruk Psikologis. Pada dimensi tersebut hanya menggunakan exploratory factor analisis dan hasilnya terdapat 5 faktor yang membentuk dimensi tersebut. Dimensi berbeda konstruk dan merupakan dimensi yang multidimensional.

Validitas konstruk alat ukur ini dianggap kurang baik karena dasar teori konstruk ini kurang mantap dan masih mengacu pada prososial dan tidak berdiri sendiri. Definisi secara operasional dari kesalehan sosial ini bukan merupakan konstruk psikologis tetapi aspek-aspek dari definisi konsep kesalehan sosial dan prososial mendekati kesamaan sehingga bisa dipadukan. Penelitian yang dilakukan oleh (Part \& Sciences, 2014) menyatakan bahwa konsep keagamaan dapat diukur dan masuk dalam kajian psikologi agama maupun psikoreligiusitas. Konsep keagamaan yang aspek-aspeknya memiliki kesamaan dengan konstruk psikologis dapat dipadukan sebagai penelaahan konsep agama dalam kajian scientis. 
Hasil pengujian skor T menunjukkan bahwa sebanyak 49,27\% termasuk dalam kategori rendah dan sebanyak 50, $72 \%$ termasuk kategori tinggi. Antara yang memiliki kesalehan sosial yang tinggi dengan rendah seimbang. Hal ini bisa dipengaruhi oleh budaya. Budaya indonesia tertanam untuk saling membantu sesama tanpa pamrih kepada sesama. Seuai dengan penelitian (Part \& Sciences, 2014) yang menyatakan bahwa konsep keagamaan yang memiliki aspek kesamaan dengan konstruk psikologi juga dipengaruhi oleh budaya.

\section{SIMPULAN DAN IMPLIKASI}

Berdasarkan hasil analisis data pada alat ukur kesalehan sosial dengan menggunakan korelasi item - total dengan Product Moment terdapat 27 item yang diterima dan 14 item yang tidak diterima. Reliabilitas $\mathrm{rxx}=0.797$

Penelitian ini merupakan penelitian awal sehingga perlu diadakan revisi khususnya dasar teori mengenai konstruk yang hendak diukur. Saran yang dapat diberikan adalah alat ukur ini dapat digunakan sebagai alat ukur yang mengungkap tentang kesalehan sosial individu karena seluruh item telah memenuhi seluruh kawasan domain ukur. Bagi peneliti selanjutnya diharapkan untuk merevisi item item yang dianggap memiliki korelasi item yang rendah sehingga dapat dijadikan sebagai alat ukur yang akurat. Selain itu, aspek aspek dalam alat ukur kesalehan sosial yang dianggap saling tumpang tindih maka bisa direduksi.

\section{REFERENSI}

Aghababaei, N. (2014). God, the good life, and HEXACO: The relations among religion, subjective well-being and personality. Mental Health, Religion and Culture, 17(3), 284-290. https://doi.org/10.1080/13674676.2013.797956

Bufford, R. K., Blackburn, A. M., Sisemore, T. A., Bassett, R. L., Bufford, Rodger K.Blackburn, Amanda M.Sisemore, Timothy A.Bassett, R. L., Bufford, R. K., ... Bassett, R. L. (2015). Preliminary Analyses of Three Measures of Grace: Can They be Unified? Journal of Psychology \& Theology, 43(2), 86-97. Retrieved from http://web.b.ebscohost.com/ehost/detail/detail?vid=20\&sid=fc90ac82-cf72-4220bad3-

5ac939f19e81@sessionmgr112\&hid=102\&bdata=JnNpdGU9ZWhvc3QtbGl2ZSZz Y29wZT1zaXRl\#AN=2015-27097-

002\&db=psyh\%5Cnhttp://digitalcommons.georgefox.edu/cgi/viewcontent.cgi?articl $\mathrm{e}=1107 \&$

Miyatake, S., \& Higuchi, M. (2017). Does religious priming increase the prosocial behaviour of a Japanese sample in an anonymous economic game? Asian Journal of Social Psychology, 20(1), 54-59. https://doi.org/10.1111/ajsp.12164

Moltafet, G., Mazidi, M., \& Sadati, S. (2010). Personality traits, religious orientation and happiness. Procedia - Social and Behavioral Sciences, 9, 63-69. https://doi.org/10.1016/j.sbspro.2010.12.116 
Part, B., \& Sciences, S. (2014). Econstor, 9(3), 276-284. https://doi.org/10.1037/rel0000136

Riadi H. 2014. Kesalehan sosial sebagai parameter kesalehan keberislaman ( ikhtiar baru dalam menggagas mempraktekan taukhid sosial) An nida: jurnal pemikiran islam, vol 39: no 1 januari-juli

Sears, David O.Fredman, Jonathan L., \&Peplau, L.A .1994.Psikologi sosial jilid 2. Alih Bahasa: Michael Adryanto. Jakarta. Erlangga

Suryabrata,S (2000). Penyusunan Alat Ukur Psikologi. Yogyakarta Pustaka Pelajar Zuhri S. 2014. Pendidikan Transformasi Kesalehan Sosial Individu Menuju Kesalehan Sosial Diera Globalisasi.Naskah Publikasi.Progam Studi Magister Pendidikan Islam. Sekolah Pasca Sarjana Uinversitas Muhammadiyah Surakarta. Tidak Dipublikasikan.

Widiarso, W. 2009. Modul Statistik. Fak Psikologi UGM. Tidak Diterbitkan

Artikel Dosen Comments Off on Kesalehan Individual dan Kesalehan Sosial (Dr. $\mathrm{Hj}$. Helmiati, M.Ag) 19th August 2015. Diunduh 3 Januari 2018

KH A. Mustofa Bisri*http://kesalehansosial.blogspot.co.id. diunduh tgl 3 januari 2018

http://sodikinmuhammad.blogspot.co.id/2011/12/hubungan-ibadah-dan-kesalehansosial_04.htm. Diunduh 3 januari 2018s 